\title{
Natural products and Chagas' disease: the action of triterpenes acids isolated from Miconia species
}

\author{
Daniele da Silva Ferreira, Viviane Rodrigues Esperandim, Maria Gabriela Marçal, \\ Nayara Bruna dos Reis Neres, Nayanne Larissa Cunha, Márcio Luís Andrade e Silva, \\ Wilson Roberto Cunha $\bowtie$
}

\begin{abstract}
The protozoan Trypanosoma cruqi i causes Chagas' disease, a neglected illness that remains a relevant public health concern in Latin America. In Brazil, Benznidazole is available for its treatment. This compound is effective against circulating forms of the parasite in the acute phase of the disease, but its efficacy during the chronic stage is debatable. The search for new medications that can treat Chagas' disease is therefore mandatory. Natural sources display a wide range of secondary metabolites and may play an important role in the discovery of new potential drugs. Miconia is one of the largest genus of the family Melastomataceae and includes approximately 1,000 plant species; Brazil alone is home to approximately 250 of these species, which exist in forests and savannas. Studies on the various biological activities of the Miconia species have reported promising results. Several researchers have screened these plants as well as their extracts in vitro against trypomastigote forms of T. cruzi, which displayed significant trypanocidal activity. It has been demonstrated that the presence of ursolic and oleanolic determines this biological activity.
\end{abstract}

Keywords: Chagas' disease; Trypanosoma cruzi; Miconia.

Edited by Gonzalo Sequeda $\square$ \& Alberto Acosta

Universidade de Franca - Núcleo de Pesquisa em Ciências Exatas

e Tecnológicas da Universidade de Franca, Av. Dr. Armando Salles Oliveira, 201, 14404-600 Franca, SP, Brazil

Received: 25-05-2013 Accepted: 16-08-2013

Published on line: 13-09-2013

Citation: da Silva Ferreira D, Rodrigues Esperandim V, Marçal MG, Bruna dos Reis Neres N, Larissa Cunha N, Andrade e Silva ML, Cunha WR (2013) Natural products and Chagas' disease: the action of triterpenes acids isolated from Miconia species. Universitas Scientiarum 18(3): 243-256 doi: 10.11144/Javeriana.SC18-2.npcd

Funding: CAPES, CNPq, São Paulo Research Foundation (FAPESP).

Electronic supplementary material: N/A

SICI: 2027-1352(201309/12)18:3<243:NPACDTAOTAIFMS>2.0.TS;2-X

\section{Introduction}

Neglected tropical diseases (NTDs) are lifethreatening or disabling infections affecting more than a billion people worldwide. Underprivileged populations living in remote rural areas, urban slums, or conflict zones, often in underdeveloped and developing countries, are at the highest risk of acquiring NTDs. Consequently, people suffering from these diseases constitute an unattractive market to private-sector research. This situation is a matter of significant concern-NTDs not only affect health directly, but they also represent an impasse of socioeconomic impact that perpetuates poverty in a sizable number of the population (Schmidt et al. 2012a). 
An estimated 1.2 billion people are currently infected with NTDs; about one billion of these people live on less than $\$ 1$ per day. In some areas, women and children with NTDs are considered as neglected populations, because they have limited access to health and social support services. Other vulnerable groups that face poverty and live under the impact of NTDs include peri-urban slum dwellers (Herrera et al. 2011). The major effects of NTDs on public health stem from chronic conditions that result in disfigurement as well as lifelong disability and morbidity (Hotez et al. 2009).

The drugs that are currently available to treat NTDs have long been in the market and exhibit many toxic effects (Lemke 2012); this makes the search for more effective and safer medications to fight these conditions mandatory. However, a fundamental problem regarding NTDs is to convince pharmaceutical companies to invest resources and develop effective treatments: the population affected by these diseases cannot afford expensive drugs (Dimitri 2012).

An evaluation of the drugs approved by the FDA (Food and Drug Administration) between 2007 and 2011 shows that only five of the 119 approved medications belong to the class of antimicrobials (antibiotic, antimycobacterial, antiprotozoal, and antifungal agents) (Mullard 2011).

Seventeen NTDs exist, including three major protozoan diseases: human African trypanosomiasis (HAT or "sleeping sickness"), Chagas' disease, and leishmaniasis, which affect many millions of people worldwide. In 2009, an estimated 10 million people were infected with Chagas' disease, and the estimated number of annual deaths was 10,000. In turn, leishmaniases cause approximately 50,000 deaths annually. As for HAT, the total number of infected people in 2006 was 50,000-70,000 (WHO 2010), although the number of new infections appears to be dwindling (Schmidt et al. 2012a).

The protozoan Trypanosoma cruzi is the etiological agent of Chagas' disease. It is estimated that there are eight million inhabitants infected with this disease in Latin America; 30-40\% has or will develop cardiomyopathy or mega digestive syndrome (Parker \& Sethi 2011). The life cycle of T. cruzi implicates hematophagous triatomine insect (vectors), a wide range of vertebrate mammalian hosts and different developmental forms of the parasite. Briefly, after insect vectors ingest bloodstream trypomastigotes from an infected mammalian host, T. cruqi forms convert into epimastigotes that proliferate and then differentiate into metacyclic forms inside the posterior intestine of the triatomine. These infective parasite forms are discharged in the feces of the triatomine and can invade new vertebrate cells, in which they undergo another round of differentiation into the intracellular amastigote forms. The latter proliferate and transform back to trypomastigotes, the form that disseminates the infection (Soeiro \& Castro 2011).

Although effective efforts to control vectorial and blood transmission have significantly reduced the number of new cases, there are still many challenges that need to be confronted regarding Chagas' disease. The disease has a peculiar epidemiology, characterized by a variety of risk factors, several potential vectors and reservoirs, different forms of transmission, and a number of parasite isolates in domiciliary, peridomiciliary, and sylvatic environments; furthermore, prophylactic therapies and effective chemotherapeutic schemes are virtually inexistent (Coura 2007).

Chagas' disease constitutes a complex condition in which $T$. cruzi effectively invades human cells. All transmission routes involve infective but non-proliferative trypomastigotes entering the bloodstream and eluding the immune system by permeating a variety of cell types, including muscle and nerve cells of the heart and the gastrointestinal tract, as well as cells of the reticuloendothelial system. Tissue damage in the mammalian host results from both direct parasite action and an inflammatory process. The initial acute phase has low $(<10 \%)$ mortality and generally presents mild and unspecific symptoms. Macrophages, IFN-gamma, and CD4+ and CD8+ Th1 lymphocytes are the key elements controlling parasite replication (Urbina 2010). 
A life-long chronic condition follows the acute phase of Chagas' disease. In the chronic stage, the cellular immune response limits parasite proliferation but cannot eradicate the infection (Albareda et al. 2006). The most severe of these manifestations is chronic Chagas cardiomyopathy (CCC), which typically appears decades after the initial infection, and may result in cardiac arrhythmia, ventricular aneurysm, congestive heart failure, thromboembolism, and sudden cardiac death. This condition is the leading cause of cardiac disease and cardiac death in underprivileged, rural, and ruraloriginated urban populations, in Latin America (Rassi et al. 2009).

Nifurtimox and Benznidazole are the two drugs currently available to treat chagasic patients; however, their toxicity is well known as well as their limited effect on different parasite isolates and disease phases making the discovery of novel medications extremely urgent. Nifurtimox, which is produced and used mainly in Central America but not Brazil, has a high incidence of side effects (reported by $40 \%$ of patients), which include nausea, vomiting, abdominal pain, weight loss, severe anorexia, and adverse neurological effects such as restlessness, paresthesias, twitching, insomnia, and seizures (Marin-Neto et al. 2009).

Available in Brazil, nitroheterocyclic Benznidazole is used to treat Chagas' disease. Benznidazole is effective against the circulating form of the parasite (trypomastigotes) in the acute phase of the disease, but its efficacy during the chronic stage is debatable (Silva et al. 2013). Compared to Nifurtimox, Benznidazole has fewer side effects such as hypersensitivity (dermatitis, generalized edema, ganglionic infarction, and joint and muscle pains), bone marrow depletion, and peripheral polyneuropathy (Coura 2009). Benznidazole is produced by LAFEPE (Laboratório Farmacêutico do Estado de Pernambuco, Recife, Brazil); supported by recent DNDi (Drugs for Neglected Diseases initiative) efforts, it will begin to manufacture a pediatric formulation (Soeiro \& Castro 2011). Because of the limited efficacy of the currently available drug treatments and the lack of a vaccine, controlling the transmission of the etiological agent in endemic areas necessarily depends on reducing the vector home population through insecticide spraying programs, improved housing conditions, and campaigns to raise awareness in vulnerable communities. Infection by T. cruzi, in particular, is likely to remain endemic in sylvatic hosts despite spraying and insect control efforts. Contemporary drug treatments fall short in treating this disease because of the long life span of infected human hosts, its resistance to triatomine insecticides, and the ease with which protozoans develop resistance to the drugs (Diotaiuti et al. 1995, Murta \& Romanha 1998, Vassena et al. 2000).

Given the significant limitations of the medications currently available, particularly their inability to treat chronic patients, new steps have been taken toward specific chemotherapeutic approaches for the management of Chagas' disease (Urbina 2010). Natural sources such as plants exhibit a wide diversity of secondary metabolites and may play an important role as new drug leads (Schmidt et al. 2012b).

\section{Research into natural products}

In developing and less developed countries, underprivileged communities have used traditional plant-based curative applications and medicinal products since ancient times. Chemical substances derived not only from plants, but also from animals and microorganisms have long been employed to treat a number of human diseases. In fact, drug discovery studies based on natural toxins and their derivatives have culminated in the development of many therapeutic agents (Tempone et al. 2007).

The research, development, and use of natural products as therapeutic agents, especially those derived from higher plants, have increased significantly (Gurib-Fakim 2006). Commonly, the plant part subjected to the extraction procedure is the same as the one used in traditional medicine; however, other parts should be assessed, to determine which section contains the highest concentration of the active compounds. Because it is not certain whether only the most polar compounds will display the best action, activity 
screening should use solvents of different polarities to extract the substances (Izumi et al. 2010).

Scientists have isolated several primary metabolites from plants, for example, vincristine, vinblastine, taxol, podopyllotoxin, and morphine. Many of these compounds have been modified, to yield better analogues in terms of activity, toxicity, and solubility (Hostettmann et al. 1997).

A preliminary investigation of chemical constituents is motivating; it provides information about the extracts and indicates the nature of its constituents, facilitating the selection of chromatographic techniques. The organic compounds should be identified by infrared spectroscopy (IR), which determines the presence or absence of functional groups; by ultraviolet spectroscopy (UV), which shows whether the compounds bear combined unsaturated bonds; by hydrogen and carbon-13 nuclear magnetic resonance spectroscopy $\left({ }^{1} \mathrm{H}-\mathrm{NMR}\right.$ and ${ }^{13} \mathrm{C}-\mathrm{NMR}$, respectively), which determines the nature and chemical environment of hydrogens and carbons, respectively, and represents the most important technique when investigating molecular structure; and by mass spectrometry (MS), which furnishes data on the weight and molecular formula, and helps identify the fragments typical of the molecule (Maciel et al. 2002).

Novel technologies that include recombinant pathogens and rapid detection methods are contributing to the development of drugs for the treatment of neglected diseases. About ten years ago, the advent of high-throughput screening (HTS) technology revolutionized the process of early drug development, enabling researchers to rapidly collect enormous amounts of data and explore compound libraries with unprecedented thoroughness (Phatak et al. 2009). One of the fastest HTS systems is Lucio Freitas-Junior's at the Institute Pasteur in Korea: a 384-well cell-culture system that combines an automated confocal microscope with an image analyzer that can screen up to 30,000 compounds a week (Clayton 2010). In 2011, Andriani et al. (2011) also reported the advantages of using HTS for the discovery of drugs to treat neglected diseases.
The use of antiparasitic drugs is common worldwide; fittingly, incidences of parasite resistance to some of these drugs are frequent. As a result, alternative treatments, especially those involving natural products, have emerged over the last years (Santos et al. 2012). In the past decades, several research groups have described the effect of plant-derived compounds on T. cruzi in the particular case of trypanosomiasis (Grael et al. 2000).

More recent studies have reported on compounds isolated from natural products that are active against T. cruzi. Veiga-Santos et al. (2013) demonstrated the antitrypanosomal activity of the amides piperovatine and piperlonguminine isolated from Piper ovatum against epimastigotes ( $\mathrm{IC}_{50}$ of $41.5 \pm 0.7$ and $53.8 \pm 6.2 \mu \mathrm{M}$, respectively) and intracellular amastigotes $\left(\mathrm{IC}_{50}\right.$ of $35 \pm 6.9$ and $33.9 \pm 5.4 \mu \mathrm{M}$, respectively).

Similar to other high incidence diseases, basic research in Chagas' disease is characterized by a large number of studies conducted on animal models infected by Trypanosoma cruzi. Different aspects of the human disease are reproduced after infection with Trypanosoma cruzi in mice (Sato et al. 1992), hamsters (Santos-Buch \& Teixeira 1974), rabbits (Ramirez et al. 1994), Rhesus monkeys (Galvão-Castro et al. 1984) and dogs (Andrade et al. 1984).

Several studies have also analyzed the in vivo trypanocidal activity of substances isolated from pepper. Esperandim et al. (2013), for example, evaluated the in vivo therapeutic properties of (-)-cubebin, a compound isolated from the dry seeds of Piper cubeba, and (-)-Hinokinin, prepared by (-)-cubebin oxidation. Results revealed increased cell nuclei in untreated infected animals as compared to uninfected mice. The values obtained for infected animals treated with (-)-cubebin and (-)-hinokinin were close to those observed for uninfected mice. For the spleen, perimeter values of $10.85 \mu \mathrm{m}(\mathrm{p}<0.01)$ and $10.90 \mu \mathrm{m}(\mathrm{p}<0.05)$ were obtained for mice treated with (-)-cubebin 50 $\mathrm{mg} / \mathrm{kg}$ and (-)-hinokinin $20 \mathrm{mg} / \mathrm{kg}$, respectively, whereas untreated infected animals provided a perimeter of $11.76 \mu \mathrm{m}$. Saraiva et al. (2010) loaded 
(-)-hinokinin onto poly (D, L-lactide-co-glycolide) microparticles and revealed that the treatment of infected mice with $40 \mathrm{mg} / \mathrm{kg}$ of (-)-hinokininloaded microparticles, every 2 days could bring about a significant decrease in parasitemia levels in comparison with those recorded in untreated controls $(\mathrm{P}<0.05$ at days 12, 14,16, 19, and 21 post-infection with T. cruqi).

Laurella et al. (2012) evaluated the trypanocidal activity of the Argentinean Mikania species. The organic extracts of $M$. micrantha, $M$. periplocifolia, M. parodii, and M. cordifolia displayed significant antiprotozoal activity against $T$. cruzi epimastigotes and L. braziliensis promastigotes in vitro. The authors suggested that terpenoids, mainly sesquiterpene lactones and diterpenes, present in the genus Mikania accounted for the antitrypanosomal activity.

Escobar et al. (2010) have reported that essential oils obtained from different species of Lippia spp, a widely distributed genus of Colombian plants, exhibited important activity against Leishmania chagasi and Trypanosoma crugi.

Despite all the efforts by researchers from different countries, the treatment of Chagas' disease has seen little progress. Experiments with active compounds isolated from plants have shown that modifying the molecule increases activity significantly; however, scientists rarely perform such alterations to the original compound, perhaps overlooking opportunities to find new drugs. There are many advantages to studying the medicinal benefits of natural products. In the case of Chagas' disease, the prospect of developing new drugs has led to the screening of the antitrypanosomal activity of almost 400 species belonging to more than 100 plant families over the last 15 years (Izumi et al. 2010).

Ursolic acid (1) and oleanolic acid (2) (Figure 1) both compounds and triterpenoids are widely distributed in the plant kingdom and have been frequently isolated as isomeric mixtures. Several articles have exposed an abundant interest in these triterpenoids including their isolation, chemical modifications, and pharmacological and toxicological studies (Liu 2005).
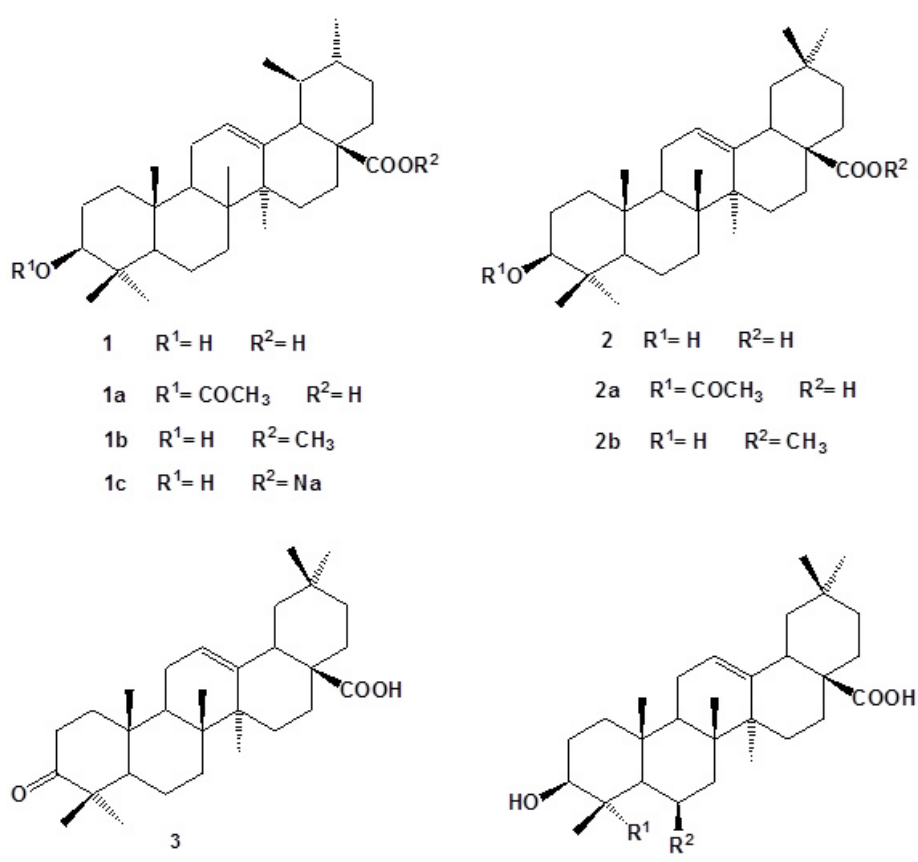

$$
\begin{array}{rlrl}
4 & \mathrm{R}^{1} & =\mathrm{CH}_{3} & \mathrm{R}^{2}=\mathrm{OH} \\
5 & \mathrm{R}^{1}=\mathrm{COOH} & \mathrm{R}^{2}=\mathrm{H}
\end{array}
$$
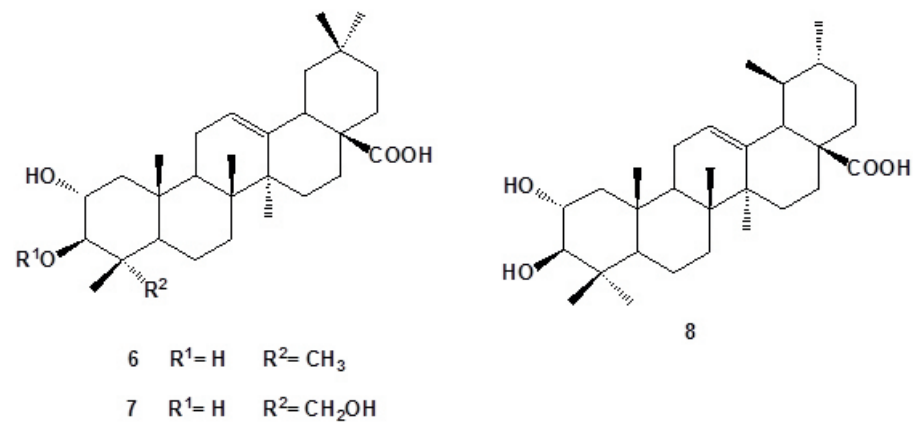

Fig. 1. Chemical structures of the triterpenes acids isolated from Miconia species and synthetic derivatives tested for trypanocidal activity. Figure from Cunha WR, et al:: In Vitro Trypanocidal Activity of Triterpenes from Miconia Species. Planta Med 2003; 69:470-472. Reproduced with kind permission from Georg Thieme Velag KG.

Compounds 1 and 2 effectively protect laboratory animals from chemically induced liver injury. In China, compound $\mathbf{2}$ has been marketed as an oral drug for human liver disorders. The hepatoprotective mechanism of these two compounds may inhibit toxic activation and enhance the body's defense systems (Liu 1995). 
Triterpenoids have also been found to have antiparasitic activity against Plasmodium falciparum (Steele et al. 1999), Trypanosoma (Leite et al. 2006), and Leishmania species (Torres-Santos et al. 2004). They have also been reported to exert biological activity against Mycobacterium tuberculosis (Gua et al. 2004), and potential antiviral activity against HIV (Ovesna et al. 2004). Despite the biological activities displayed by these triterpenoids, further studies are necessary to explain their action mechanisms.

Miconia species contain triterpenes, coumarins, and benzoquinones (Gunatilaka et al. 2001). Miconia extracts and their isolated compounds display remarkable biological activities, such as antitumoral (Cunha et al. 2008), analgesic and antiinflammatory actions. Ursolic acid and oleanolic acid are just two of the many biologically active substances that can be isolated from Miconia species. Fittingly, this genus may greatly contribute to the discovery of new drugs derived from natural products.

The genus Miconia: a natural source of biologically active substances against Trypanosoma cruzi

Melastomataceae is one of the main families of neotropical flora, with about 5,000 species belonging to 185 genera and 11 tribes. The interest in these plants stems from its eye-catching flowers; in Brazil, Miconia, the largest genus of the Melastomataceae family, is represented by about 250 ornamental species (Martins et al. 1996, Marcon \& Costa 2000). It is native to the forests of Central and South America extending from southern Mexico, in the north, toward the south through Guatemala, British Honduras, Nicaragua, Costa Rica, Panama, Colombia, Ecuador, Peru, Bolivia, Brazil, Paraguay, and northern Argentina.

The biological properties of some Miconia species have drawn researchers' attention; extracts and isolated compounds exhibit antibiotic, antitumoral, analgesic, and antimalarial activities (Hasrat et al. 1997, Cunha et al. 2003, Serpeloni et al. 2008). Our team has been working with Miconia species and has tested several of their biological actions, including the trypanocidal activity of isolated compounds and structurally modified molecules. We have also screened Miconia plant extracts against trypomastigote blood forms of T. cruzi in vitro and have found that methylene chloride extracts of $M$. fallax and $M$. stenostachya showed significant antitrypanosomal activity.

In 2003, we conducted a study in our laboratory (Cunha et al. 2003), which demonstrated that some compounds isolated from methylene chloride extracts of $M$. fallax and $M$. stenostachya present a trypanocidal effect. Using spectroscopic methods-MS, and ${ }^{1} \mathrm{H}$ - and ${ }^{13} \mathrm{C}-\mathrm{NMR}$, this same study elucidated the structure of the isolated compounds and synthetic derivatives. To assay trypanocidal activity according to a previous report (Grael et al. 2000), we elicited lysis of bloodstream trypomastigotes of the $\mathrm{Y}$ strain of T. cruzi by adding the isolated compounds and their synthetic derivatives to the infected blood. Ursolic (1) and oleanolic (2) acids were the major components of the methylene chloride extract of M. fallax, which also contained oleanolic (3) and sumaresinolic (4) acids (Figure 1). A previous study on $M$. stenostachya revealed the presence of sumaresinolic and gypsogenic (5) acids (Figure 1). We treated the mixture of compounds $\mathbf{1}$ and $\mathbf{2}$ with excess acetic anhydride in pyridine, to obtain the C-3 acetoxy derivatives $1 \mathrm{a}$ and $\mathbf{2 a}$ which, in $\mathrm{CH}_{2} \mathrm{~N}_{2}$ and $\mathrm{Et}_{2} \mathrm{O}$, yielded a mixture of C-28 methyl ester derivatives $\mathbf{1 b}$ and $\mathbf{2} \mathbf{b}$ (Figure 1 ). Table 1 shows lysis percentages of T. cruzi tripomastigotes forms induced by addition to the infected blood of the isolated compounds and their synthetic derivatives. The natural compounds $\mathbf{1}, \mathbf{2}$, and $\mathbf{5}$, which contain $\mathrm{OH}$ and $\mathrm{COOH}$ groups, provided the lowest $\mathrm{IC}_{50}$ values $(21.3,80.4$, and $56.6 \mu \mathrm{M}$, respectively); the synthetic derivatives afforded higher $\mathrm{IC}_{50}$ values (Table 1). The presence of polar groups appeared critical to the trypanocidal activity.

As part of our ongoing search for potential trypanocidal compounds, in our laboratory, we also fractionated the methylene chloride active extracts of M. sellowiana Naud. and M. ligustroides (DC.) Naudin. and identified other triterpenes acids active against the trypomastigote forms of T. cruzi (Cunha et al. 2006). This latter work, employed 
Table 1. In vitro trypanocidal activity of triterpenes isolated from two Miconia species and their synthetic derivatives against the Y strain of Trypanosoma cruqi. ${ }^{a}$ Positive control. ${ }^{b}$ Mice infected blood containing the same DMSO used in the stocks solution (negative control) did not present reduction of the parasite number. Table 1 from Cunha WR, et al:: In Vitro Trypanocidal Activity of Triterpenes from Miconia Species. Planta Med 2003; 69:470-472. Reproduced with kind permission from Georg Thieme Velag KG.

\begin{tabular}{lcccc}
\hline \multirow{2}{*}{ Compounds } & \multicolumn{2}{c}{$\%$ lysis \pm S.D./concentration $(\mu \mathrm{M})^{\mathrm{b}}$} & \multirow{2}{*}{$\mathrm{Ic}_{50}(\mu \mathrm{M})$} \\
\hline 1 & 100 & 250 & 500 & \\
\hline 2 & $91.1 \pm 1.4$ & $95.5 \pm 0.7$ & $99.6 \pm 0.7$ & 21.3 \\
\hline Mixture 1 + 2 & $69.2 \pm 7.4$ & $90.7 \pm 2.5$ & $99.2 \pm 0.7$ & 80.4 \\
\hline Mixture 1a + 2a & $60.3 \pm 3.7$ & $91.1 \pm 1.4$ & $95.1 \pm$ & 109.4 \\
\hline Mixture 1b + 2b & $2.8 \pm 4.8$ & $15.8 \pm 11.0$ & $16.9 \pm 6.7$ & $4,238.9$ \\
\hline 3 & $42.9 \pm 4.4$ & $44.1 \pm 0$ & $47.4 \pm 5.1$ & 610.5 \\
\hline 4 & $19.8 \pm 8.3$ & $76.4 \pm 11.5$ & $97.2 \pm 1.4$ & 294.9 \\
\hline 5 & $46.6 \pm 4.8$ & $47.4 \pm 5.1$ & $70.4 \pm 1.8$ & 402.3 \\
\hline Gentian violet ${ }^{\mathrm{a}}$ & $73.1 \pm 8.4$ & $97.4 \pm 2.9$ & $100 \pm 0$ & 56.6 \\
\hline
\end{tabular}

a methodology different from that previously reported in Cunha et al. (2003); we tested other isolated triterpenes, and assessed their activity against T. cruzi $i$ trypomastigotes by using the MT'T colorimetric method [MTT, 3-(4,5-dimethylthiazol2-yl)-2-5-diphenyltetrazolium bromide] using low concentrations of the compounds. Vacuum liquid chromatography of the methylene chloride extract of M. sellowiana over $400 \mathrm{~g}$ of silica gel 60 provided fractions F2 and F3. After filtration of over $60 \mathrm{~g}$ of a celite:norit mixture, the elution of the combined fractions F2 and F3 with methylene chloride produced $350 \mathrm{mg}$ of compound 1 . The ${ }^{1} \mathrm{H}$ - and ${ }^{13} \mathrm{C}-\mathrm{NMR}$ data of this solid revealed the presence of a mixture of maslic acid (6) and $2 \alpha$-hydroxyursolic acid (8) (Figure 1).

Vacuum liquid chromatography of the methylene chloride extract of $M$. ligustroides (6.5 g) on silica gel with increasing proportions of the same organic solvents used to fractionate the $M$. sellowiana extract, produced arjunolic acid (7) and a mixture of compounds 1 and 2 . Purification of the latter mixture by HPLC yielded compound 2 and the potassium salt derivative of 1 (1c) (Figure 1). The in vitro biological assay of compounds $\mathbf{1}$ and 2 on the trypomastigote forms of T. cruzi (obtained by culturing the $\mathrm{LLMCK}_{2}$ cell lineage) using the MTT colorimetric (Muelas-Serrano et al. 2000) indicated that compounds 1 and 2 were the most active amongst the isolated compounds, with $\mathrm{IC}_{50}$ of 17.1 and $12.8 \mu \mathrm{M}$, respectively (Table 2). The $\mathrm{IC}_{50}$ value of the mixture of compounds 1 and 2 was lower than those achieved for the pure acids 1 and $\mathbf{2}$ in isolation, suggesting a synergistic effect. The potassium salt derivative of $\mathbf{1}$ (1c) was more potent $\left(\mathrm{IC}_{50} 8.9 \mu \mathrm{M}\right)$ than its active parent acid 1 . In contrast, a mixture of compounds $\mathbf{6}$ and $\mathbf{8}$ was much less potent than a mixture of $\mathbf{1}$ and 2. Finally, compound 7 (Figure 1) displayed weak trypanocidal activity $\left(\mathrm{IC}_{50}=76.3 \mu \mathrm{M}\right)$ when compared with the other triterpenes. 
Table 2. Results of the in vitro trypanocidal activity of the isolated compounds and synthetic derivatives. Gentian violet (positive control) displayed $\mathrm{IC}_{50}=31 \mu \mathrm{M}$. The negative control, RPMI-1640 medium plus 1\% DMSO, displayed $0 \%$ lysis. Table 2 from Cunha WR, et al: A study of trypanocidal activity of triterpene acids isolated from Miconia species. Phytother Res 2006; 20:474-478. Reproduced with kind permission from John Wiley \& Sons, Ltd.

\begin{tabular}{|c|c|c|c|c|}
\hline \multirow{2}{*}{ Compounds } & \multicolumn{3}{|c|}{$\%$ lysis \pm S.D. $/$ concentration $(\mu \mathrm{M})^{\mathrm{b}}$} & \multirow{2}{*}{$\mathrm{Ic}_{50}(\mu \mathrm{M})$} \\
\hline & 8 & 32 & 128 & \\
\hline 1 & $33.0 \pm 12.4$ & $68.2 \pm 2.6$ & $75.7 \pm 10.1$ & 17.1 \\
\hline $1 a$ & $40.4 \pm 5.9$ & $68.9 \pm 3.4$ & $68.2 \pm 3.4$ & 12.8 \\
\hline Mixture $1+2$ & $50.2 \pm 2.5$ & $69.7 \pm 11.9$ & $68.2 \pm 7.9$ & 5.4 \\
\hline $1 \mathrm{c}$ & $49.4 \pm 2.2$ & $59.9 \pm 14.6$ & $71.1 \pm 7.9$ & 8.9 \\
\hline Mixture $6+8$ & $36.7 \pm 22.6$ & $38.2 \pm 13.7$ & $63.7 \pm 6.9$ & 48.5 \\
\hline 7 & $23.2 \pm 25.5$ & $45.7 \pm 13.5$ & $53.2 \pm 10.1$ & 76.3 \\
\hline
\end{tabular}

We tested the most active compounds in vivo using mice (swiss albino) infected with approximately $2 \times 10^{4}$ trypomastigote forms. The treatment group received a daily intraperitoneal injection of the tested compound at a concentration of $2 \mathrm{mg} \mathrm{kg}^{-1}$ for 13 days. The number of parasites was counted according to the technique described by Brener (1962); the in vivo trypanocidal activity was expressed as the percentage of $T$. cruzi trypomastigote lysis. We also evaluated the animals' survival time; compound 1 and its derivative salt 1c reduced parasites in the parasitemic peak more significantly $(75.7 \%$ and $70.4 \%$, respectively), increasing the survival time for all the treated animals. The results indicated that the structural variable most consistently influencing the activity were the hydroxyl groups at C-2, C-23, and C-28. Taking into account that a mixture of compounds $\mathbf{6}$ and $\mathbf{8}$ was much less active than the mixture of compounds 1 and 2 , we inferred that hydroxylation at C-2 decreased the trypanocidal activity. In the same way, hydroxylation at C-23 (compound 4) should also diminish the in vitro activity against $T$. cruzi. In principle, this reduction might be interpreted as the result of the increased polarity of compounds $\mathbf{6 , 7}$, and $\mathbf{8}$ as compared to compounds $\mathbf{1}$ and $\mathbf{5}$. Compound $\mathbf{1 c}$ (much more polar than compound 1) was most potent. Thus, introducing an additional hydroxyl at the A-ring (at C-2 or C-23) may affect trypanocidal activity, may develop an intramolecular hydrogen bond with the hydroxyl at C-3, or the additional hydroxyl may hinder binding to the enzymatic site. On the basis of these results, we concluded that the free hydroxyl at C-3 and the polarity of C-28 determines the in vitro trypanocidal activity of triterpenes, at least for the analyzed set of compounds.

Ferreira et al. (2010) examined the in vitro and in vivo trypanocidal activity of compounds 1 and 2 against the Bolivian strain of T. cruzi. They also evaluated the acute toxicity of these compounds by determining the median lethal dose $\left(\mathrm{LD}_{50}\right)$ and quantifying its biochemical parameters. The authors undertook the in vitro trypanocidal assay according to the protocol established by Cunha et al. (2006). For the in vivo assay, BALB/C albino mice received $20 \mathrm{mg} \mathrm{kg}^{-1}$ of the target compound orally, on a daily basis, for 20 days. The number of parasites was quantified according to the technique described by Brener (1962); the in vivo trypanocidal activity was expressed as the percentage of trypomastigote lysis. 
In vitro, compound 1 proved to be a more active trypanocidal agent than compound 2; $\mathrm{IC}_{50}$ values were 45.2 and $25.5 \mu \mathrm{M}$, respectively. Corroborating the in vitro assays, in vivo assays showed that compound 1 reduced the number of parasites at the parasitemic peak more significantly $(60 \%)$ than compound 2 (40\%). Additionally, all the animals treated with compound 1 survived longer as compared with the negative control. The presence of a hydroxyl group and a carboxyl group is important for the trypanocidal effect of both compounds 1 and 2 (Cunha et al. 2006, Leite et al. 2006). However, while compound 1 contains methyl groups at C19 and C20, compound 2 has two methyl groups at C20; this implies that the methyl group at C19 enhances trypanocidal activity against the Bolivian strain, which is more resistant to chemotherapy with Benznidazole (Ribeiro et al. 1988, Martinez-Díaz et al. 2001). The lethal dose $\left(\mathrm{LD}_{50}\right)$ in $\mathrm{BALB} / \mathrm{C}$ albino mice receiving a single oral dose of the tested terpenoid at a concentration of 2,000 mg kg-1, as determined by the Litchfield \& Wilcoxon method (1949) after $72 \mathrm{~h}$ (Pires et al. 2004), did not evidence mortality or toxicity. Hence, it is totally safe to use these compounds in trials involving a much lower dose $(20 \mathrm{mg} / \mathrm{kg} /$ day $)$.

Biochemical parameters, were measured using male Wistar rats that received compounds 1 and 2 at concentrations of 20 and $50 \mathrm{mg} \mathrm{kg}^{-1}$ for 20 days; their diet was normal and drinking water was available to them ad libitum. At the end of the experimental period, the animals were sacrificed. Their blood was collected, to measure serum aspartate amino transferase (AST), serum alanine amino transferase (ALT), alkaline phosphatase (ALP), gamma-glutamyltranspeptidase (GGT), bilirubin, glucose, urea, and creatinine levels, to obtain information about liver and kidney functions. Neither compound $\mathbf{1}$ nor compound $\mathbf{2}$ altered the levels of these biochemical parameters, deeming these substances safe for experimental tests. One of the most important properties of these compounds is their antioxidant capacity. Martin-Aragón et al. (2001) suggested that compound 1 may prevent the initiation and propagation of the lipid peroxidation process as it scavenges free radicals through conjugation with glutathione, controlling oxidative damage and tissue protection. Recent studies have also confirmed that compounds 1 and 2 offer antioxidative protection and exert hepatoprotective effects (Saravanan et al. 2006, Liu et al. 2012).

The most recent study by our group researched the effects of compounds $\mathbf{1}$ and $\mathbf{2}$ on interleukin levels by comparing treated and untreated chagasic mice (Ferreira et al. 2013). For the in vivo assay, we administered daily doses of 20 and $50 \mathrm{mg}$ of the target drug kg-1 for 20 days to male BALB/C albino mice by oral and intraperitoneal means. We counted the number of trypomastigotes following the method described by Brener (1962) to evaluate parasitemia. For the cytokine assays, we treated mice with $20 \mathrm{mg} \mathrm{kg}^{-1}$ of the substances; collected plasma samples seven days post-infection, and measured $\gamma$-IFN and IL-10 concentrations using a specific two-site enzyme-linked immunosorbent assay (ELISA).

Intraperitonealdelivery of $20 \mathrm{mg} \mathrm{kg}^{-1} \mathrm{compounds}$ 1 and $\mathbf{2}$ did not significantly affect the $\mathrm{Y}$ strain of T. cruzi as compared with control groups. Similarly, $50 \mathrm{mg} \mathrm{kg}^{-1}$ of these compounds did not reduce the number of circulating parasitic forms; treatment with these triterpenes did not enhance survival, either. On the other hand, orally administered compound 1 (20 $\left.\mathrm{mg} \mathrm{kg}^{-1}\right)$ decreased the number of parasites by approximately $30 \%$ as compared with the negative control group. However, $50 \mathrm{mg}$ $\mathrm{kg}^{-1}$ oral compounds 1 and 2 exhibited significant biological activity against the $\mathrm{Y}$ strain of T. cruzi, reducing parasite burden by $79 \%$ and $76 \%$ at the parasitemic peak, respectively. Additionally, all the mice treated with these triterpene acids displayed longer survival time compared to the negative control group. Animals treated with these substances presented significantly lower $\gamma$-INF concentrations, which explains the exacerbated parasitemia detected in these mice; treated animals also displayed elevated IL-10 concentrations. The results from intraperitoneal administration were unexpected; earlier studies on animals infected with the same T. cruzi strain and treated with $2.0 \mathrm{mg} /$ $\mathrm{kg} /$ day compounds 1 and 2 showed significantly reduced parasitemic levels and increased survival times (Cunha et al. 2006). However, the cytokine 
assays performed by our group demonstrated significantly diminished $\gamma$-IFN levels. This effect could account for the exacerbated parasitemia because $\gamma$-IFN is associated with host resistance during the acute phase of infection. In contrast, treatment with compounds 1 and 2 elicited significantly higher IL-10. Various studies have reported that increased susceptibility of infected animals correlates with enhanced production of the anti-inflammatory cytokine IL-10 (Minoprio et al. 1993, Reed et al. 1994). Our results are consistent with previous works; they demonstrate that treatment with triterpenes suppresses the production of proinflammatory cytokines such as $\gamma$-IFN and generates IL-10 (Nataraju et al. 2009, Martín et al. 2010). Therefore, compounds 1 and 2 initiate an immunosuppressive effect that could interfere with host parasitemia control. The significantly reduced parasitism observed with oral administration of compound 1 may be due to its low absorption in the bowels, as verified in a recent study evaluating ursolic acid pharmacokinetics after oral administration (Jeong et al. 2007). In conclusion, orally administered compound 2 was more effective in our study, possibly because it is less absorbed by the intestines, which leads to fewer immune alterations and better control of the number of parasites.

\section{Conclusion}

Controlling or eliminating NTDs could bring millions of people out of poverty; it could increase access to education, because NTDs currently infect more than 400 million school-aged children in the developing world. Treating these children's infections is the single most cost-effective way to boost school attendance, opening the door to growth and learning for the next generation of workers. Additionally, controlling and eliminating NTDs strengthens worker productivity, contributing hundreds of billions of dollars to developing economies through increased worker productivity (Franco-Paredes et al. 2007).

However, economic consideration by the pharmaceutical industry outweighs all other benefits. Returns on development costs are unsatisfactory; consequently, it is necessary to find cheaper alternatives to treat Chagas' disease. This could be achieved by increasing the activity of the presently used anti-Chagasic drugs, or by modifying the host's immune response, which would make current therapies more effective (Maya et al. 2007). Some research groups have focused their research on finding a safe and reliable therapeutic drug to eradicate the parasite as well as a prophylactic drug to enhance human blood prior to transfusion (Mckerrow et al. 2009).

Studying natural substances yields valuable results, especially against diseases for which a cure does not yet exist or for which a treatment is available but its administration is challenging for the patient. Determining the efficacy of a tested drug or its optimum concentration is very important; however, providing information on target drugs, parasite biology, or drug interaction with the host cell is a valuable additional stride (Maya et al. 2007).

Several studies of Miconia plant extracts against trypomastigotes blood forms of $T$. cruq $i$ have demonstrated significant trypanocidal activity. The isolated triterpenes ursolic and oleanolic acids were the most active compounds against T. cruqi. Nevertheless, more studies on the derivatives of these two compounds and on other triterpenoid acids are vital, to elucidate structure-activity relationships and develop novel therapeutic agents against Chagas' disease.

\section{Acknowledgment}

We would like to thank CAPES, CNPq for fellowships, and São Paulo Research Foundation (FAPESP), grant number 2012/16182-8 for financial support.

\section{Conflict of Interest}

The authors have no conflict of interest.

\section{References}

Albareda MC, Laucella SA, Alvarez MG, Armenti AH, Bertochi G, Tarleton RL, Postan M (2006) Trypanosoma cruzi modulates the profile of memory CD8+ T cells in chronic Chagas' disease patients. International Immunology 18 (3): 465-71 
Andrade ZA, Andrade SG, Sadigursky M (1984) Damage and healing in the conducting tissue of the heart (an experimental study in dogs infected with Trypanosoma cruz?). The Journal of Pathology 143 (2): 93-101

Andriani G, Chessler AD, Courtemanche G, Burleigh BA, Rodriguez A (2011) Activity in vivo of antiTrypanosoma cruæi compounds selected from a high throughput screening. Plos Neglected Tropical diseases 5 (8): 1298

Brener Z (1962) Therapeutic activity a criterion of cure on mice experimentally infected with Trypanosoma cruzi. Revista do Instituto de Medicina Tropical de São Paulo 4: 389-396

Clayton J (2010) Chagas disease: pushing through the pipeline. Nature 24: 465(7301): 12-5

Coura JR (2007) Chagas disease: what is known and what is needed - A background article. Memórias do Insituto Oswaldo Cruz 102 (1): 113-22

Coura JR (2009) Present situation and new strategies for Chagas disease chemotherapy - a proposal. Memórias do Insituto Oswaldo Cruz 104 (1): 549-54

Cunha WR, Martins C, Ferreira DS, Crotti AEM, Lopes NP, Albuquerque S (2003) In vitro trypanocidal activity of triterpenes from Miconia species. Planta Medica 69 (5): 468-70

Cunha WR, Crevelin EJ, Arantes GM, Crotti A E, Silva MLA, Furtado NA, Ferreira DS (2006) A study of trypanocidal activity of triterpene acids isolated from Miconia species. Phytotherapy Research 20 (6): 474-8

Cunha WR, Silva MLA, Dos Santos FM, Montenegro IM, Oliveira ARA, Tavares HR, Leme dos Santos HS, Da Silva JCB (2008) In vitro inhibition of tumor cell growth by Miconia fallax. Pharmacentical Biology 46 (4): 292-294

Diotaiuti L, Pereira AS, Loiola CF, Fernandes AJ, Schofield JC (1995) Inter relation of sylvatic and domestic transmission of Trypanosoma cruzi in areas with and without domestic vectorial transmission in Minas Gerais. Memórias do Instituto Oswaldo Cruz. 90 (4): 443-448

Dimitri N. (2012) R\&D investments for neglected diseases can be sensitive to the economic goal of pharmaceutical companies. Drug Discovery Today 17 (15-16): 818-823

Escobar P, Leal SM, Herrera LV, Martinez JR, Stashenko E (2010) Chemical composition and antiprotozoal activities of Colombian Lippia spp essential oils and their major components. Memórias do Instituto Oswaldo Cruz 105 (2): 184-190
Esperandim VR, Ferreira DS, Rezende KCS, Cunha WR, Saraiva J, Bastos JK, Silva MLA, Albuquerque S (2013) In vivo infection by Trypanosoma cruzi: a morphometric study of tissue changes in mice. Experimental Parasitology 133 (1): 442-446

Ferreira DS, Esperandim VR, Toldo MPA, Saraiva J, Cunha WR, Albuquerque S (2010) Trypanocidal activity and acute toxicity assessment of triterpene acids. Parasitology Research 106 (4): 985-9

Ferreira DS, Esperandim VR, Toldo MP, Kuehn CC, do Prado Júnior JC, Cunha WR, Silva MLA, Albuquerque S (2013) In vivo activity of ursolic and oleanolic acids during the acute phase of Trypanosoma cruzi infection. Experimental Parasitology 134 (4): 455-9

Franco-Paredes C, Von A, Hidron A, RodríguezMorales AJ, Téllez I, Barragán M (2007). Chagas disease: an impediment in achieving the Millennium Development Goals in Latin America. BMC International Health and Human Rights 7:7.

Galvão-Castro B, Sá-Ferreira JÁ, Pirmez C (1984) Immunopathological aspects of American Trypanosomiasis: the role of immune complexes in the pathogenesis of the disease. Memórias do Instituto Oswaldo Cruz 79: 69-76

Grael CF, Vichnewski W, Souza GE, Lopes JL, Albuquerque S, Cunha WR (2000) A study of the trypanocidal and analgesic properties from Lychnophora granmongolense (Duarte) Semir \& Leitão Filho. Phytotheraphy Research 14 (3): 203-206

Gua JQ, Wang Y, Franzbalu SG, Motenegro G, Timmermann BN (2004) Constituintes of Quinchamalium majus with potencial antitubercular activity. Zeitschrift für Naturforschung C, Journal of Biosciences 59 (11-12): 797-802

Gunatilaka AAL, Berger JM, Evans R, Miller JS, Wisse JH, Neddermann KM, Bursuker I, Kingston DGI (2001) Isolation, synthesis and structure-activity relationships of bioactive benzoquinones from Miconia lepidota from the Suriname rainforest. Journal of Natural Products 64 (1): 2-5

Gurib-Fakim A (2006) Medicinal plants: traditions of yesterday and drugs of tomorrow. Molecular Aspects of Medicine 27 (1): 1-93

Hasrat JA, De Backer JP, Valquelin G, Vlietinck AJ (1997) Medicinal plants in Suriname: screening of plants extracts for receptobinding activity. Phytomedicine 4 (1): 56-65

Herrera JS, Franco-paredes C, Santos-Preciado JI (2011) The global burden of neglected tropical diseases. Boletín Médico del Hospital Infantil de México 68 (2): 78-82 
Hostettmann K, Wolfender JL, Rodriguez S (1997) Rapid detection and subsequente isolation of bioactive constituents of crude plant extracts. Planta Medica 63 (1): 2-10

Hotez PJ, Fenwick A, Savioli L, Molyneux DH (2009) Rescuing the "bottom billion" through control of neglected tropical diseases. Lancet 373 (9674): 1570-5

Izumi E, Ueda-Nakamura T, Dias Filho BP, Veiga Júnior VF, Nakamura CV (2010) Natural products and Chagas' disease: a review of plant compounds studied for activity against Trypanosoma cruzi. Natural Product Reports 28 (4): 809-823

Jeong DW, Kim YH, Kim HH, Ji HY, Yoo SD, Choi WR, Lee SM, Han CK, Lee HS (2007) Dose-linear pharmacokinetics of oleanolic acid after intravenous and oral administration in rats. Biopharmaceutics and Drug Dispositions 28 (2): 51-57

Laurella LC, Frank FM, Sarquiz A, Slonso MR, Gibert G, Cavallaro L, Catalan CA, Cazorla SI, Malchiodi E, Martino VS, Sulsen VP (2012) In vitro evaluation of antiprotozoal and antiviral activities of extracts from argentinean Mikania Species. The Scientific World Journal 121 (153): 1-6

Leite JPV, Oliveira AB, Lombardi JA, Filho JDS, Chiari E (2006) Trypanocidal acitvity of triterpnes from Arrabidaea triplinervia and derivatives. Biological \& Pharmaceutical Bulletin 29 (11): 2307-2309

Lemke TL (2012) Antiparasitic Drugs. In: Lemke TL, Williams DA, editors. Foye's principles of medicinal chemistry. Seventh edition. Sixth edition. Lippincott Williams \& Wilkins. New York, pp 1125-1157

Litchfield JT, Wilcoxon F (1949) A simplified method of evaluating dose-effect experiments. The Journal of Pharmacology and Experimental Therapeutics 96 (2): 99-113

Liu CH, Huang XT, Li YY, Zheng X, Li N, Mi SQ, Wang NS (2012) The anti-portal hypertension effect of oleanolic acid in CCl4-induced cirrhosis rats. Zhong Yao Cai 35 (6): 930-5

Liu, J (1995) Pharmacology of oleanoic acid and ursolic acid (Review). Journal of Ethnopharmacology 49 (2): 57-68

Liu, J (2005) Oleanoic acid and ursolic acid: research perspectives. Journal of Ethnopharmacology 100 (1-2): 92-94

Maciel MAM, Pinto AC e Veiga JVF (2002) Plantas medicinais: a necessidade de estudos multidisciplinares. Química Nova 25 (3): 429-438

Marcon ML, Costa CG (2000) Anatomia da madeira de quatro espécies do gênero Miconia Ruiz \& Pavón (Melastomataceae). Rodriguésia 51 (78-79): 5-20
Marin-Neto JA, Rassi JA, Avezum JA, Matto AC, Rassi A, Morillo CA, Sosa-Estani S, Yusuf S (2009) The BENEFIT trial: testing the hypothesis that trypanocidal therapy is beneficial for patients with chronic Chagas heart disease. Memórias do Instituto Oswaldo Cruz 104 (1): 319-24

Martin-Aragón S, De Las Heras B, Sanchez-Reus MI, Benedi J (2001) Pharmacological modification of endogenous antioxidant enzymes by ursolic acid on tetrachloride-induced liver damage in rats and primary cultures of rat hepatocytes. Experimental and Toxicologic Pathology 53 (2-3): 199-206

Martín R, Carvalho-Tavares J, Hernández M, Arnés M, Ruiz-Gutiérrez V, Nieto ML (2010) Beneficial actions of oleanolic acid in an experimental model of multiple sclerosis: a potential therapeutic role. Biochemical Pharmacology 79 (2): 198-208

Martinez-Díaz RA, Escario JÁ, Nogal-Ruiz JJ, GómezBarrio A (2001) Relationship between biologicaI behaviour and randomly amplified polymorphic DNA profiles of Trypanosoma cruzi $i$ strains. Memórias do Instituto Oswaldo Cruz 96 (2): 251-256

Martins AB, Semir J, Goldenberg R, Martins E (1996) O gênero Miconia Ruiz \& Pav. (Melastomataceae) no Estado de São Paulo. Acta Botanica Brasilica 10 (2): 267-315

Maya JD, Cassels BK, Iturriaga-Vásquez P, Ferreira J, Faundez M, Galanti N, Ferreira A, MORELLO A (2007) Mode of action of natural and synthetic drugs against Trypanosoma cruzi ind their interaction with the mammalian host. Comparative Biochemistry and Physiology Part A, Molecular \& Integrative Physiology 146 (4): 601-20

Mckerrow JH, Doyle PS, Engel JC, Robertson SA, Ferreira R, Saxton T, Arkim M, Kerr ID, Brinen LS, Craik CS (2009) Two approaches to discovering and developing new drugs for Chagas disease. Memórias do Instituto Oswaldo Cruz.104 (1): 263-269

Meyer, JY (1997) Epidemiology of the invasion by Miconia calvescens and reasons for a spectacular success, J-Y Meyer \& CW Smith (eds), Proceedings of the first regional conference on Miconia control. Papeete, Tahiti, French Polynesia, Gouvernment de Polynésie française/University of Hawaii at Manoa/Centre, pp 26-29

Minoprio P, El-Cheikh MC, Murphy E, HontebeyrieJoskowicz M, Coffman R, Coutinho A, O'Garra A (1993) Xid-associated resistance to experimental Chagas' disease is IFN- $\gamma$ dependent. Journal of Immunology 151 (8): 4200-4208

Muelas-Serrano S, Nogal-Ruiz JJ, Gómez-Barrio A (2000) Setting of a colorimetric method to determine the viability of Trypanosoma cruzi epimastigotes. Parasitology Research 86 (12): 999-1002 
Mullard A. (2011) FDA drug approvals. Nature Reviews Drug Discovery 11 (2): 91-94

Murta SM, Romanha AJ (1998) In vivo selection of a population of Trypanosoma cruzi and clones resistant to benznidazole. Parasitology 11 (2): 165-171

Nataraju A, Saini D, Ramachandran S, Benshoff N, LIU W, Chapman W, Mohanakumar T (2009) Oleanolic acid, a plant triterpenoid, significantly improves survival and function of islet allograft. Transplantation 88 (8): 987-994

Ovesna Z, Vachalkova A, Horvathova K, Tothova D (2004) Pentacyclic triterpenoic acids: new chemoprotective compounds. Minreview. Neoplasma 51 (5): 327-333

Parker ER, Sethi A (2011) Chagas Disease: Coming ]to a place near you. Dermatoligic Clinics 29 (1): $53-62$

Phatak SS, Stephan CC, Cavasotto CN (2009) Highthroughput and in silico screenings in drug discovery. Expert Opinion Drug Discovery 4 (9): 947-959

Pires OC, Taquemasa AVC, Akisue G, Oliveira F, Araújo CEP (2004) Análise preliminar da toxicidade aguda e dose letal mediana ( $\mathrm{LD}_{50}$ ) comparativa entre os frutos de Pimenta-do-Reino do Brasil (Schinus terebinthifolius Raddi) e Pimenta do Reino (Pipernigrum L.). Acta Farmaceutica Bonaerense 23 (2): 176-182

Ramírez LE, Lages-Silva E, Soares Júnior JM, Chapadeiro E (1994) The hamster (Mesocricetus auratus) as experimental model in Chagas' disease: parasitological and histopathological studies in acute and chronic phases of Trypanosoma cruzi infection. Revista da Sociedade Brasileira de Medicina Tropical 27 (3): 163-9

Rassi Jr, Dias JC, Marin-Neto JA, Rassi A (2009) Challenges and opportunities for primary, secondary, and tertiary prevention of Chagas' disease. Heart 95 (7): 524-534

Reed SG, Brownell CE, Russo DM, Silva JS, Grabstein KH, Morissey PJ (1994) IL-10 mediates susceptibility to Trypanosoma cruzi infection. Journal of Immunology 153 (7): 3135-3149

Ribeiro RD, Lopes RA, Carmo TA, Rissato TA (1988) Indice de cura de camundongos tratados com nifurtimox e benzonidazol na doença de Chagas experimental. Revista de Ciências Farmacêuticas 10: 71-76

Santos-Buch CA, Teixeira AR (1974) The immunology of experimental Chagas' disease. 3. Rejection of allogeneic heart cells in vitro. The Journal of Experimental Medicine 140 (1): 38-53
Santos RC, Alves CFS, Schneider T, Lopes LQ, Aurich C, Giongo JL, Brandelli A, Vaucher RA (2012) Antimicrobial activity of Amazonian oils against Paenibacillus species. Journal Invertebrate Pathology 109 (3): 265-268

Saraiva J, Lira AAM, Esperandim VR, Ferreira DS, Ferraudo AS, Bastos JK, Silva MLA, Gaitani CM, Albuquerque S, Marchetti JM (2010) (-)Hinokinin-loaded poly(D,L-lactide-co-glycolide) microparticles for Chagas disease. Parasitology Research 106 (3): 703-708

Schmidt TJ, Khalid SA, Romanha A, Alves TMA, Biavatti MW, Brun R, Da Costa FB,de Castro SL, Ferreira VF, de Lacerda MVG, Lago JHG, Leon LL, Lopes NP, das Neves Amorim RC, Niehues M, Ogungbe IV, Pohlit AM, Scotti MT, Setzer WM, M. Soeiro MNC, Steindel M and Tempone AG (2012a) The Potential of Secondary Metabolites from Plants as Drugs or Leads Against Protozoan Neglected Diseases - Part I. Current Medicinal Chemistry 19 (14): 2128-2175

Schmidt TJ, Khalid AS, Romanha AJ, Alves TMA, Biavatti MW, Brun RB, Costa FB, Castro SL, Ferreira VF, Lacerda MGV, Lago JHG, Leon LL, Lopes NP, Amorim RCN, Niehues M, Ogungbe IV, Pohlit AM, Scotti, MT, Setzer WN, Soeiro MNC, Steindel M, Tempone AG (2012b) The potential of secondary metabolites from plants as drugs or leads against protozoan neglected diseases - Part II. Current Medicinal Chemistry 19 (14): 2176-2228

Silva RB, Loback VB, Salomão K, Castro SL, Wardell JL, Wardell SMSV, Costa TEMM, Penido C, Henriques MGMO, Carvalho AS, Silva EF, Fraga CAM (2013) Synthesis and Trypanocidal Activity of Novel 2,4,5-Triaryl-N-Hydroxylimidazole Derivatives. Molecules 18 (3): 3445-3457

Saravanan R, Viswanathan P, Pugalendi KV (2006) Protective effect of ursolic acid on ethanolmediated experimental liver damage in rats. Life Sciences 78 (7): 713-718

Sato MN, Yamashiro-Kanashiro EH, Tanji MM, Kaneno R, Higuchi ML, Duarte AJ (1992) CD8+ cells and natural cytotoxic activity among spleen, blood, and heart lymphocytes during the acute phase of Trypanosoma cruri infection in rats. Infection Immunity 60 (3): 1024-30

Serpeloni MS, Vilegas W, Varanda EA, Cólus IMS (2008) In vivo evaluation of anticlastogenicity of extracts from medicinal plants of Miconia genus using the micronucleus test. Semina: Ciências Biológicas e da Saúde 29 (1): 47-56 
Soeiro MNC, Castro SL (2011) Screening of Potential anti-Trypanosoma cruzi candidates: In vitro and in vivo studies. The Open Medicinal Chemistry Journal 5: 21-30

Steele JC, Warhurst DC, Kirby GC, Simmonds MS (1999) In vitro and in vivo evaluation of betulinic cid as an antimalarial. Phytotherapy Research 13 (2): 115-119

Tempone AG, Melhem MSC, Pado FO, Motoie G, Hiramoto RM, Antoniazzi MM, Haddad CFB, Jared C (2007) Amphibiam secretions for drug discovery studies: a search for new antiparsitic and antifungal compounds. Letters in Drug Design \& Discovery 4 (3): 67-73

Torres-Santos EC, Lopes D, Oliveira RR, Carauta JP, Falcao CA, Kaplan MA, Rossi-Bergmann B (2004) Antileishmanial activity of isolated triterpenoids from Pourouma guianensis. Phytomedicine 11 (2-3): $114-120$

Productos naturales y mal de Chagas: la acción de los ácidos triterpenos aislados de especies de Miconia.

Resumen. El protozoario Trypanosoma cruzi causa mal de Chagas, enfermedad que aún es problema de salud pública relevante en América Latina. El fármaco disponible en Brasil para el tratamiento es benznidazol. Este compuesto es eficaz contra la forma de circulación del parásito en la fase aguda de la enfermedad, pero su eficacia durante la fase crónica es discutible. Por lo tanto, la búsqueda de nuevos medicamentos que pueden tratar el mal de Chagas es necesaria. Las fuentes naturales presentan amplia gama de metabolitos secundarios y pueden desempeñar papel importante en el descubrimiento de nuevas drogas potenciales. Miconia es un género de los más grandes perteneciente a la familia Melatomateceae, incluyendo cerca de 1.000 especies de plantas; sólo en Brasil hay aproximadamente 250 de estas especies en florestas y sabanas. Los estudios sobre las diversas actividades biológicas de las especies Miconia han presentando resultados promisorios. Varios autores han evaluado extractos de estas plantas contra $T$. cruzi, comprobando que estos exiben actividad tripanocida significativa. La presencia de ácidos ursólico y oleanólico determinan la actividad biológica.

Palabras clave: Mal de Chagas; Trypanosoma cruzi; Miconia.
Urbina JA (2010) Specific chemotherapy of Chagas disease: Relevance, current limitations and new approaches. Acta Tropica 115 (1-2): 55-68

Vassena CV, Picollo MI, Zerba EN (2000) Insecticide resistance in Brazilian Triatoma infestans and Venezuelan Rhodnius prolixus. Medical and Veterinary Entomology 14 (1): 51-55

Veiga-Santos P, Desoti VC, Miranda N, UedaNakamura T, Dias-Filho BP, Silva SO, Corteza DAG, Mello JCP, Nakamura CV (2013) The natural compounds piperovatine and piperlonguminine induce autophagic cell death on Trypanosoma cruzi. Acta Tropica 125 (3): 349-56
Produtos naturais e doença de Chagas: a açáo de triterpenos ácidos isolados de espécies de Miconia.

Resumo. A doença de Chagas é uma doença negligenciada causada pelo protozoário Trypanosoma cruzi e ainda permanece como um relevante problema de saúde pública na América Latina. O medicamento disponível para o tratamento clínico no Brasil é o benzonidazol, que é efetivo contra as formas circulantes do parasita na fase aguda da doença, entretanto, sua eficácia na fase crônica permanece discutível. A pesquisa por novas drogas que possam ser utilizadas no tratamento dessa doença é urgentemente necessária e as fontes naturais com os seus metabólitos secundários diversificados, podem desempenhar um papel extremamente importante. Miconia é um dos maiores gêneros pertencente à família Melastomataceae incluindo cerca de 1.000 espécies e, no Brasil existem cerca de 250 espécies em florestas e savanas. Estudos realizados com o objetivo de descrever as diferentes atividades biológicas de espécies de Miconia têm apresentado resultados promissores. Vários autores têm avaliado os extratos dessas plantas contra as formas tripomastigotas sanguíneas de T. cruzi (in vitro) e verificado que essas amostras exibem atvidade tripanocida significativa. A presença dos triterpenos ácidos ursólico oleanólico está relacionada com esta atividade biológica.

Palavras-chave: Doença de Chagas; Trypanosoma cruð̣i; Miconia. 